\title{
On Eugene O’Neill Inheritance to Greek Tragedy in Desire Under the Elms
}

\author{
JING Jing \\ Changchun University, Changchun, China
}

\author{
HUO Feng-chun \\ NO.20 Junior Middle School of Siping, Siping, China
}

\begin{abstract}
In Desire Under the Elms, Eugene O’Neill not only adopts some elements from Greek tragedies, but brings more different ideas for readers, such as supernaturalism, and the degeneration of the tragic heroes or the peasant like language and sets more comic elements. Under his powerful pen, a marvelous drama is displayed before the audience, which combines the traditional elements and modern creations perfectly. This paper aims to explore the important elements in the play and compare those with what are used in Desire Under the Elms so as to draw the conclusion that Eugene O’Neill not only uses the traditional written skills but also improves the development and inheritance of Greek tragedies.
\end{abstract}

Keywords: Greek tragedy, development, inheritance

\section{Introduction}

Eugene O'Neill is unquestionably American greatest playwright who won Noble Prize for literature in 1936. He wanted contemporary American drama to achieve the power of ancient Greek tragedies. Before O'Neill's time, Americans saw only imported plays from Europe, melodrama's farces and sentimental comedies. O'Neill wrote 45 plays which were highly experimental in form and style, combining literary theories of symbolism, naturalism, and expressionism. He had a great influence on later American playwrights, and on those of other countries. With Desire Under the Elms, Eugene O'Neill establishes himself a playwright of genius. Desire Under the Elms describes a complex relationship. The setting falls on the Cabot family farmhouse in New England in spring, 1850. Desire Under the Elms basically chronicles a triangle love story among father, son, and step mother. Eben, resembling his gentle mother, hates Ephraim for having mistreated and stolen the farm from her. He toils on the farm with his two elder half-brothers, Simeon and Peter, for the unanimous avaricious interest in inheriting it. When Ephraim, after a lengthy, unannounced absence, returns with a new bride less than half his age, Simeon and Peter, depart to seek gold in California, having relinquished their "rights" to the farm to Eben, in exchange for the money they need to head west. When Ephraim exults over the birth of his supposed son, and reveals that the newly-born child will inherit the property, Eben repudiates Abbie's love, which is by now genuine. She kills the child and in a rage confesses her crimes. Eben informs the sheriff, but overcome by the love for Abbie, admits a part in the murder, and is arrested with her. The paper focuses on the inheritance and development of Greek

JING Jing, Master, Lecturer, School of Foreign Languages, Changchun University.

HUO Feng-chun, Master, Senior Teacher of Middle school, NO.20 Junior Middle School of Siping. 
Tragedy in Eugene O’Neill's Desire Under the Elms based on the basic content, feature, and the value.

\section{Origination of the Forces of O'Neill's Tragic Vision}

The age O'Neill lived in was the transitional period when America developed from the free capitalism to monopoly capitalism. It witnessed not only the booming and depression in economy but also the crisis of Americans.

In 1917, many young men, in response to the call of President Wilson to make the whole world safe for democracy, went into the First World War with an unusual amount of economic booming period. The whole country enjoyed a large-scale prosperity brought about by its advanced techniques, innovations in electricity and modern productions. The Americans were caught up in the illusion that there was money everywhere. However, the history proved otherwise. The great progress in science and technology brought no dignity to the general public. Human beings became the slave of their own machine, and lifeless tools for the capital holders to make money. Meanwhile, the loss of faith, which began noticeably with Darwin's theorized of evolution and was intensified by the development of modern science, continued with a greater intensity into his century. Darwin argued that existing species, including human beings, had evolved from less complex forms of life, for example, monkeys, through a long process of "nature selecting” (Normand,1998, p. 45). Those species adapted themselves to survival by reason of quickness, shrewdness or other advantages, while others fell by the wayside. This theory, together with other intellectual currents, like Nietzsche’s postulate “God is dead” (Normand, 1998, p. 72). and Marxism, functioning like a bomb, gave the Christian people a heavy blow by contradicting a literal interpretation of the creation Genesis. Man was no longer the creation of God.

Living in a cold, indifferent, and essentially godless world, man was no longer free in any sense of that world. He was completely thrown up himself for survival. The world in which God was good, warm, and caring enough to the wrong of wizards was gone not to return. The comfortable belief that man could hope to fall back on divine help and guidance was exploded and irretrievably lost.

At that time, O'Neill's view of the human condition and mankind's prospect had long been darkening. He deeply felt a sense of isolation, alienation, and degeneration prevailing the whole America. The onslaught of his own tragedy all together with what he observed and perceived from his experience compelled O'Neill to draft his ground-breaking portrayal of a family destroyed by desire. The anger towards a stoic stingy patriarch in Desire Under the Elms, mirrors O’Neill's resentment against his as evil as Ephraim father, James O’Neill, which is more obviously depicted in Long Day's Journey Into Night. Mr. Tyrone, the father, makes fuss at the use of the lights, trying to save every penny at the cost of the health of his wife and the life of his younger son. Moreover, the near-incestuous affair between Eben and Abbie alluded to Jamie, Eugene O'Neill's brother's obsessive adoration of their drug-addict mother.

Greek tragedy is said to have originated "from the ode to Dionysus (god of wine), lamenting his suffering in earthly world and eulogizing his revitalization” (YANG, 1997, p. 35). The pre-Socratic Greeks could not endure individuals on the tragic stage, for thus they could not feel the Dionysian oneness in themselves and in the universe, which is probably the reason why the protagonists in the plays of Aeschylus and Sophocles often wear masks, virtually embalming the original hero Dionysus. Tragedy, in this sense, played, as it were, a holy religion in the ancient Greek life, and Greek tragedy, for O’Neill, was the unsurpassed paragon of art and religion. This 
religious spirit was just what he found in completely short in modern American life; therefore the playwright set a goal for himself to recreate it in his works. Tragedy, as far as he was concerned, might be the best way to achieve this goal, thus, it becomes a major part of O’Neill's writing.

\section{O’Neill's Inheritance to Greek Tragedy}

In Desire Under the Elms of Eugene O'Neill, the drama inherits the traditional Greek tragedies from various perspectives such as the plots, the main elements, and the supernaturalism.

“Oedipus Complex" named by Freud derives from the Greek tragedy Oedipus Rex by Sophocles in which the king Oedipus kills his father and marries his mother. "We are dealing", wrote the psychiatrist appall, "with a real case of psycho-sexual fixation on the mother, with its concomitant feature-hatred of the father" (Bogard, 1986, p. 103). There is always a rivalry between father and son for the mother's love. Eben's constant hatred to his father can be observed throughout the play. At the very beginning, Eben has said: “I pray he’s died” (O'Neill, 1995, p. 32). And when his older brothers Simon and Peter talk about his resemblance to his father Eben denies intensely: “I’m Maw-every drop o’blood!” (O’Neill, 1995, p. 45). Although Eben's strife with his father does not end with his father's death as Oedipus does, partly because of his weakness and softness, he always seeks revenge on his father, such as stealing his money and possessing his wife. It is also obvious that Eben has a deep love for his mother. He has a close relationship with his mother and whenever he falls into trouble, his mother would be the one who comes to his mind first, whom he even elevates to the height of God and his belief in his life: "God A’ mighty! A’ mighty God! Maw, where was ye...?” (O’Neill, 1995, p. 51).

Upon the basic Oedipus relationship, the play develops a pattern of "sinister maternity". O'Neill superimposes the second voice of sinister maternity. Approaching middle age, she is in many ways another embodiment of Abbie. She is the prostitute and Eben describes his desire for. When Brother Simon reveals that "Paw" possessed her first, Eben is again aroused against his father, his old rival and antagonist.

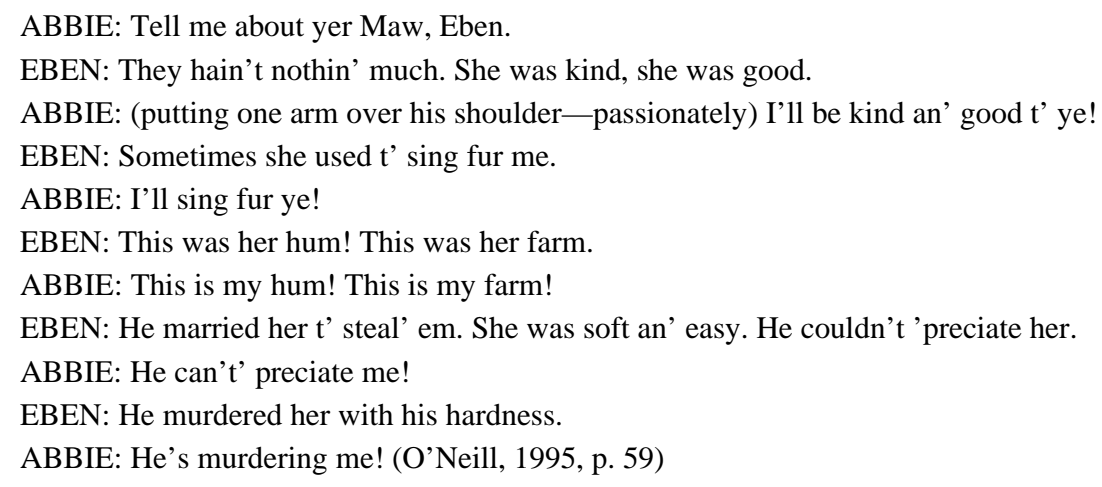

"She died" Eben grieves, and Abbie swears she'll die for him. Three times now Eben has symbolically enacted the dispossession of his father, carrying out in a sense his early prayer for old Cabot's death, which culminates in Part III with the "murderous struggle" between father and son.

The three elements: ghost, revenge, and murder are commonly used in Greek tragedy, which are most sufficiently demonstrated in Shakespeare's tragedy Hamlet. As we all know, at the beginning of the play, Hamlet's father's ghost appears and tells his son that he has been murdered by Claudius and demand revenge. 
O'Neill also invites it into his play, Desire Under the Elms. In the description of the stage setting, O'Neill has already applied such ghost-haunting atmosphere to the audience. The two big elms are the embodiment of her mother's ghost, which always cover the whole house. Especially its central room, Eben's mother's parlor, is dark and sealed away. It is a haunted room, inhabited by his mother’s ghost. "In Greek tragedy, suffering is visitation from heaven, a punishment imposed upon the hero from without” (Bogard, 1986, p. 91). Accordingly, there is always a conflict between man's free will and the supernatural.

\section{O’Neill's Improvement on Greek Tragedy}

O'Neill great achievement to Greek tragedy reflected in Desire Under the Elms mainly centers on its artistic form and the way to characterize the characters. In the play, at the party, the neighboring farmers resemble a Euripi dean chorus as they comment on Eben and Abbie's affair, the paternity of Abbie's son, and Ephraim's ignorance of the situation. "Leitmotif 'thin' serves to reveal at every turn of the action the transcendent with its inscrutable force working through the multiplicity of identifiable human motives in the play” (O’Neill, 1995, p. 43). When Eben accuses Ephraim of killing his mother, Simeon disagrees, "No one never kills nobody. It's allus some thin'. That's the murderer” (O’Neill, 1995, p. 48). This “thin” permeating the Cabot farmhouse chases Ephraim to the barn at night and frightens Abbies in the parlor. O'Neill evokes the Greek myths portrayed in Phaedra, Medea, and Oedipus the King and adapts them to an American mythical setting. Desire Under the Elms is as good a paragon as the above two in synthesizing the two forms. It is a tragedy of desire- a suppressed, disappointed and distorted desire as implied in the title. The two enormous oppressively-brooding elms provide the Cabots a smothering environment, which foreshadows a series of tragedies in the family.

O'Neill combines some creative elements with the traditional ones in Desire Under the Elms. Firstly, it should be the degradation of tragic heroes. Aristotle wrote in Poetics that tragic hero should be nobler and higher than the common people, however, O’Neill does not follow the Greek tradition and chooses a great figure of noble birth about which the fates would unreal their mystery, just as Oedipus, the king of Thebes; or Hamlet, the prince of Denmark. Rather, O’Neill was deliberately democratic and American, choosing a New England farmer and his family as the protagonists of his drama. Therefore, he lowers the tragic hero in the play, which makes the play more vivid on basis of modern life and achieves more shivering effect of pity and fear, because the tragic hero is as common as all of us, maybe even lower than us. O'Neill even reduces his tragic heroes to animals. In the presence of Eben Carot, he is described as: "his defiant, dark eyes remind one of a wild animal's in captivity" (O’Neill, 1995, p. 63). And Ephraim is always described as “a stone”. O’Neill fashions his plot with enormous detail and overwhelming emotional intensity. Characters are developed first in relation to very elemental things (like sky, stones, and land), and then in terms of structures (things like barns, fences, walls and, of course, elm trees). Values are understood through these symbols. Ephraim, Abbie, and Eben Carot are not people possessed of a care free existence. Ephraim is a hard man, and hardness to him is a virtue.

Though Desire Under the Elms is considered to be a tragedy but in the end Eben and Abbie began to recognize their love to each other. Someone may also think that it is a comic part, though their destiny will not good, they can feel each other's love. It is different form that of Greek tragedy which all have a tragic end. 


\section{Conclusion}

The ending of Desire Under the Elms is much thought-provoking. Looking around at the farm enviously, the sheriff who came to arrest the infanticide parents exclaimed, "it's a jim-dandy farm, no denying wished I owned it!” (O’Neill, 1995, p. 67). It seems to indicate that life is a cycle; living in it, nobody can escape its curse. Eben and Abee have exited from the stage, for probably they are to be hanged or imprisoned, new Ebens, Abbies, and Ephraims would be born and a new turn struggle would start soon.

All in all, Desire Under the Elms is a mirror of American society. It denounces the disastrous impacts of the myth of a material prosperity and the life-denying Puritanism on Americans through the story of the New England family, the Cabots. It also exposes O’Neill's gifted creating power, by which he recreated the Greek tragic spirit in this play. This play reveals his revulsion from American greed and indicates the kind of punishment meted out to the avaricious accumulators of wealth: moral and spiritual impoverishment. It was this play that brought the American drama into it real sense. It was his serious concern over the social issues and excellent theatrical technique shown in this play that brought the American drama into a real sense.

Eugene O’Neill, the first American dramatist to win the noble Prize for literature, brings high seriousness to the American drama and is honored as "the Maker of Modern American Drama". Desire Under the Elms is a modern tragedy containing many Greek tragedy elements, such as Oedipal conflict, the ghost, revenge, and murder in the play, and the free will versus the supernatural. Eugene O'Neill uses ancient Greek tragedy in an American farm setting in order that something of the power of the earlier dramatic literature would emerge and strengthen his own concepts. However, Eugene O’Neill will never be a mere follower, he is a creator. Eugene O'Neill brings the degradation of the tragic heroes, the peasant-like language and sets, and the more comic elements in his play. Under his powerful pen, a marvelous drama is displayed before the audience, combining the traditional elements and modern creations perfectly.

\section{References}

Normand, B. (1982). Eugene O’Neill. New York: St. Martin’s Press.

Normand, B. (1998). The Cambridge companion to Eugene O'Neill. Cambridge: Cambridge University Press.

O’Neill, E. (1995). Desire under the elms. UK: Nick Hern Books.

Kitto, H. D. F (1971). Greek tragedy. London: Methuen \& Co Ltd.

Laurie Di Mauro (1993). Twentieth-century literary criticism (Vol. 49). Detroit: Gale Research Inc.

Gerber, L. (1976). Desire under the elms—Eugene O’Neill. New Jersey: Salem Press.

Bogard, T. (1986). The historian: Mourning becomes electra and ah, wildness! Modern critical views: Eugene O’Neill. New York: Chelsea House Publishers.

YANG, Z. H. (1997). History of European literature. Peking: People’s Literature Publishing House.

ZHANG, X. (1995). Western dramas. Peking: Foreign Language Teaching and Research Press. 